SHS Web of Conferences 10, 00013 (2014)

DOI: $10.1051 /$ shsconf $/ 20141000013$

C Owned by the authors, published by EDP Sciences, 2014

\title{
Intergenerational relations in romany families
}

\author{
G. Caltova Hepnarova \\ University of Hradec Kralove, Czech Republic
}

\begin{abstract}
This paper presents partial results of the research focusing on education and protection of children in Roma families. The Roma family is regarded as a specifically closed border system. The type of family life organization is presentedin front of view of dominant values. The focus is on heavily represented values, especially esteem, solidarity end equality. Those values affect behaviour of family members and organize relations between the children and parents. The main aim of this paper is to present particularity of Roma community and specifics of relationships. The paper deals with fractional results of qualitative research project, the research survey was carried out in the year 2012, it was done as a field survey. The information, obtained on the nature of educational processes and directions of education, allowed us to crystallize key values passed in Roma families. In this paper, we focus mainly on the value of interpersonal relationships and maintaining compliance which are strongly represented in the educational efforts of Roma parents. The starting point of our considerations became the concept of values of G. Hofstede, who in his concept of value orientation reflects the cultural specifics. Above all, we focus on the values associated with collective cultures, which Roma belong to.
\end{abstract}

\section{Introduction}

Intergenerational relations within Roma families is traditionally one of the strongest bonds. In this article, these relations are viewed from the perspective of preferred values in Roma families. This text aims to reveal the essence of strong family ties that we can find among Roma. Through a deeper analysis of the meaning of the values for the formation of family relations the author attempts to explain the basic principles of the formation of interpersonal relationships in a Roma family. Values, such as solidarity, respect and brotherhood, belong to the core of being Roma, which is still in its various forms handed on to future generations. No paper has dealt comprehensively with their meaning and their role in shaping the relationship yet. In papers of individual authors, however, we find partial insights that allow us to better understand the nature of the Roma way of maintaining relationships with the loved ones. In the Czech Republic one of the most prominent authors was Milena Hübschmanová, among the most important and inspiring works, however, we must include the work by P. Říčana, J. Balvína, E. Lackové, S. Navrátila. T. Šišková. Abroad, this topic is dealt by J. Okey, J. Čorovič, W.O. Weyrauch, the pivotal work has been done by M. Steward too, who captured the lifestyles of Hungarian Roma. This paper presents the results of analytical-synthetic work with the professional resources of the listed

This is an Open Access article distributed under the terms of the Creative Commons Attribution License 4.0, which permits unrestricted use, distribution, and reproduction in any medium, provided the original work is properly cited. 
authors. The entire text has been prepared within the research project, which focuses on the educational influence of Roma families.

\section{Gender solidarity and solidarity in the family}

The Roma are one of the largest minorities living in the Czech Republic. According to some sources, as estimated by non-profit organizations working with Roma, the number of members of Roma groups in the Czech Republic is around 300,000 (Liégeois, 1995, 33). In Czech professional discourse, usually, not one Roma community is mentioned, which can be considered homogeneous, but rather the Roma communities (Navrátil, 2003, 84), extended families (Šišková, 2003, 16) and Roma enclaves (Hirt, Jakoubek, 2006, 19-21) of highly heterogeneous nature. Each of the groups that are located in the Czech Republic, is, in certain extent, unique and may not be regarded as a part of one, interconnected community of Roma. Well-known Roma solidarity is also often applied only to those locally or gender established communities.

Roma communities are traditionally considered to be very coherent and united, both in terms of horizontal and vertical solidarity. The fact that this solidarity is always conditioned by membership in one or another group is not discussed so often and it may not be fully applied to persons outside the group. Belonging to a group is usually determined by the membership of FAJT or "fameliji", although it is still distant kinship, it plays a crucial role in determining the membership of the group. On the contrary, local proximity may not play any role, it often happens that neighbours in one location are further to each other than the members of the extended family, who are separated by hundreds of kilometres. However, when there is still need for help, especially in one's own family, the Roma within their capabilities are able to help people outside of their narrower group. Solid behaviour towards other people is considered by the Roma to be one of the basic requirements of decent behaviour. Within the family this requirement becomes more important and it is inconceivable that the family members did not behave towards each other in solidarity. Solid behaviour as a value significantly affects the formation of relationships in the whole family and it plays an important role in intergenerational relations. Solidarity is the basic building block for the formation of relationships within the family group. It is followed by fraternity that plays a dominant role in shaping broader and peer relationships in the group, and then respect that shapes the form of hierarchical relationships within the group.

Many of the authors attribute solid behaviour to historical experience of Roma. Mutual aid helped extended families survive in a hostile environment and during the twentieth century it helped to face strong assimilation efforts of communist governments. M. Steward even finds two fundamental constants of Roma life; the first one is inhospitable and hostile non-Roma environment and the second one is the mutual interdependence of close relations among Roma expressed as "romanes" (Steward, 2005, 43). Šišková then drew attention to the leading of children into spirit of solidarity from the early age. Educational influence of Roma parents consciously and programmatically leads children not only to fraternal solid behaviour within the family, but they also teach to care for parents and other family members (Šišková, 2003, 16). Education of mutual solidarity is one of the aims of education, which Roma parents manage to fulfil. Along with a high degree of solidarity, in Roma families we can also find higher level of conflicts. The relationship between solidarity and conflicts within the family environment were not even found in works by Bengston, the professional of the branch of family relationships; in turn this work points out that even in families with higher levels of conflicts we can find a high degree of solidarity (Bengston, Lowenstain, 2003, 48-50). Another conclusion of Bengston's work can also be related to the situation in Roma families. Above all stands his typology of family solidarity, which he divides into five types: harmonious, isolated, sociable, intimate, binding type. Considering the situation of Roma families, it closely matches the characteristics of the two types of intergenerational relationships: sociable type and tight -knit (Silverstein, Bengtson, 1997, 429-60). 


\section{Int. Conf. SOCIETY. HEALTH. WELFARE.}

In Roma families, the relationships formed on the basis of geographical proximity dominate, but they are also strongly emotionally saturated, so the mere geographical proximity is not a condition of good relations development within the family. In the field of opinion and values, the family members reported a great match too; the relationships are additionally reinforced by frequent contacts and a high degree of mutual support, however, this may not be the rule. Solid behaviour is also the basis of family cohesion, which is another major character of Roma families. This cohesion is strengthened mainly by the time which family members spend together (Rabučicová, 2011, 75). Shared family activities play a significant role as well. Especially in the area of core activities the participation of the Roma families is frequent. Based on the model the Core and Balance Model of Family Leisure Functioning (Zabriskie, McCormick, 2001, 281-289), the predominant type of leisure activities is the so called core activities. "Core leisure patterns are described as the types of activities families do regularly, they are accessible and do not cost much". In the case of Roma families, these joint activities are manifested mainly with full participation in the life of the family (Skopalová, 2005, 115), children participate in all events, in certain activities they are passive participants of the situations, but all events concern them. Parents spend most of their time together with other family members and even children are not torn away from this environment. Zabrisky typology was made in relation to free time, in the Roma environment, however, it is manifested in a different socio-cultural context. Parents and children work together to meet household and living needs, children have their own role, the same as adults, they also spend together their free moments. In the adult age the children spend their leisure time with their parents even more often. Families visit one another and they live together for the whole days. Degree of coherence of these families is based on common experiences and it is very strong.

\section{Respect as a basis for the relationship}

Joint meeting of several generations in a limited and often confined space requires good organization of everyday activities, but also clear ordering of relations within a family. In Roma families, hierarchy and mutual respect of family members helps organize relations among the family members. In this paper we will focus only on showing respect for others. Respect, pat'iv in Romani, belongs to the still maintained and protected standard governing mutual interactions. Request for respectful behaviour is closely connected with the need to maintain good interpersonal relationships and the development of solid behaviour within the family. However, Roma expression pat'iv (respect) has a deeper meaning than in the non-Roma environment. Pat'iv is mentioned as one of the foundations of romipen (Roma ethnicity) (Stojka, 1996, 35-38). Pat'iv meant everything good, correct, honourable, noble, beneficial, useful, valuable. In traditional Roma communities pat'iv was unreservedly applied there, everybody respected it and the community protected it. Pat'iv contains in itself the principle of solidarity, which in often hostile world allowed them to survive. The antithesis of pat'iv is ladž (shame); it represented everything bad, evil, despicable, dishonest, wrong, incorrect, and unfortunate (Romipen: Pativ a ladž, 2003). Even today, despite dishonest welfare, the law Pat'iv and Ladž is still valid and it plays a dominant role in shaping the relationships in the family and community. The requirement of mandatory respect for others helps to create a cohesive environment; it reduces conflicts and positively affects selfesteem of family members. Deep respect for loved ones is a value that cannot be ignored. Respect is manifested especially with hospitable behaviour, but also with ritualized ways of behaviour in relation to the esteemed members of the community. Patrick Williams captured in his work respectful behaviour even to the dead and their subjects (things), which had a binding character for the bereaved. For example, it was not possible to sell the caravan which belonged to a dead person, or to materially benefit from his estate; there was also duty to take care for the animals of the dead (Williams, 2003, 4-6).

If someone in the family commits an act which is against the strict rules of pat'iv the whole family is burdened with shame that this act brings. The Roma expression degeš is the designation for a person who "na džanel pat'iv, na džanel pes te ladž" - does not know the meaning of honour and is not 


\section{SHS Web of Conferences}

able to be ashamed (Hubschmanová, 1999, 18). Mutual respect, to which family members are bound, is closely related to the experience of human dignity, but also with the concept of equality. "Mutual respect for the Roma is a very high value. Some Roma are so imbued with the sense of their own dignity that their inner peace and dignity reeks of them directly." (Ševčíková, 2011, 71). For functional relationships in the family and community it was necessary for members to show respect, but their actions would keep respect of the others as well. Hübschmanova speaks in this context of " $n a$ te čiel pat' $i v$ " not undermining of honour. Previously Roma used formalized methods and ritualized situations for unpleasant communication not to touch the honour of other person (Hubschmanová, 1999, 37). However, if someone broke seriously the norm, on the contrary, this offense was dealt with publicly and it was experienced by all as ladž (shame). Even today the situation is similar; one important element of social control within the Roma families and communities is public "ventilating" of wrongdoing. In the locations where our research took place, one day a younger boy (12 years old) cursed a pregnant woman. His behaviour aroused excitement throughout the community, and when the woman learned of the curse that the boy imposed on her baby she immediately solved the situation dramatically. The furious woman disconcerted this boy from a drop-in club where he was and led him to his parents, where the situation was further solved in front of the assembled crowd. In the end the whole situation for "lack of evidence" subsided to nothing. Parents assured the insulted mother that they would not tolerate such behaviour to their boy and it was out of the question for him to allow such a thing. The boy did not admit his guilt, but all the time he was keeping the penitent approach, which the assaulted woman helped to calm down. All actors of this situation parted with the understanding that such behaviour is unacceptable; the boy with the experience that curse belongs to unacceptable forms of behaviour and it directly threatens his whole family. Till today failure of pat'iv still threatens the whole family and can destabilize it. The family is at risk to be, for its disrespectful conduct, isolated from others which is social death. On the other hand, the chances of re -inclusion and forgiveness are quite high, especially if the offender publicly declares his regret and repentance. At this time Roma are favoured to rapid remission, they are also able to recognize extenuating circumstances that led to the offense. The rule of mutual human respect is still valid binding standard for all members of the community; on the basis of this rule there is "judgement" on the culprit, his punishment with public disgrace, but also forgiveness and reinstatement.

With the value of pat'iv there is also closely related the concept of equality, which the Roma recognize.

\section{Equality and brotherhood}

Equality, which is sometimes associated with the concept of brotherhood, belongs to one of the distinctive features of the Roma communities. As perception of honour, equality is a part of romipen (being Roma) and it is experienced by the Roma very differently when compared to the non-Roma. The Roma require equal dealing with others as strongly as they demand for respectful behaviour. From the perspective of the non-Roma, we sometimes think that obligatory respect and equality cannot act together, they are incompatible. In Roma families it is the opposite; respect and equality are manifested simultaneously. Workers with the Roma and researchers often point to the equal dealing with children. During the observation of Roma parents'educational activities we can actually find many situations when they deal with children in the idea of human equality and parental authority recedes into the background (Steward, 2005, 58). Parental education is permeated by the idea of equality, at the same time, however, the idea of respect is strongly anchored there, and hierarchy within the family is strictly guarded. Children growing up in this environment daily experience the respect for themselves, and at the same time they are also led to expressions of obedience and respect for older family members, even for older siblings. This method of education reinforces the concept of fraternal relations with other people, while maintaining respect for others. Steward points out that fraternal equality forming mutual relationships strengthens a tendency to homogenize life activities within the community. Based on these

$$
\text { 00013-p.4 }
$$




\section{Int. Conf. SOCIETY. HEALTH. WELFARE.}

experiences there is shaped "shared identity", which is the result of joint activities (Steward, 2005, 57-61). This paper has already noted the importance of joint activities in relation to the formation of cohesion within the family. In the case of fraternal egalitarianism jointly performed activities have a ceremonial and binding character, but we can also find an ordinary life in the wider community. In all cases, however, joint activities are an important binding element of family life.

All above mentioned values - solidarity, cohesion, respect and brotherhood -belong to the basic building blocks of being Roma. They are these values that help shape the specific form of intergenerational relationships within the family and imprint them with quirky character that non-Roma environment generally appreciates and values? Intergenerational relationships are built on the foundation of these values, although in recent years we can see the negative changes in family environment (Říčan, 1998, 44-46) yet still it is true that Roma parents manage to pass these values to their children and their educational efforts in this regard would be very successful. Despite all the social problems, poverty and conflicts Roma families are able to take care of their infirm members. It is still true that among homeless people or the elderly in residential care there is a minimum of Roma. This is understandable as the Roma are raising their children and other family members in mutual respect; they lead them to solidarity behaviour, and they build relationships on egalitarian basis, which, however, did not exclude the principle of strict gender hierarchy.

\section{Conclusions}

This article focused on explaining functioning of relationships within the Roma families. Attention was basically paid to the relationships among several generations, which together create an extended Roma family in the sense of famelija. The issue of intergenerational relationships was viewed from the perspective of dominant values that form the core of cultural capital of families. The text submitted outlines of the importance and the way of functioning of basic building blocks of the family system of Roma families, which are known for their high degree of cohesion and solidarity. Each of the mentioned values plays an important role in forming and maintaining close family ties. The requirement of mandatory respect for other people helps shape the value system in the pro-social direction; daily sharing of resource, moments and experiences creates a space for solidarity and cohesive behaviour towards members of the genus. Although family relationships are all determined on the basis of the hierarchical structure and all family members accept this arrangement, yet at the same time they are able to create an environment that is built on the ideas of brotherhood and equality. In this respect the Roma families belong to phenomenal organizational unit.

In situations when they face with social exclusion and other problems they are able to continue to educate highly loyal and dedicated members of their group.

This article was written as part of the ESF project: Development and Support of Multidisciplinary Scientific Research Team for the Study of Contemporary Family at UHK, project number CZ.1.07/2.3.00/20.0209.

\section{References}

[1] Bengston, Vern. L. Lowenstain, Ariela. (eds.) Global aging and challenges to families. New York: Aldine de Gruyter, 2003, 387s. ISBN-10: 0-202-30686-0.

[2] Hirt, Tomáš. Jakoubek, Marek. (eds.) Romové v osidlech sociálního vyloučení. 1.vyd. Plzen: Vydavatelství a nakladatelství Aleš Čeněk s.r.o., 2006. 414 s. ISBN 80-86898-76-8.

[3] Hübschmanová, Milena. Několik poznámek k hodnotám Romů. In Romové v České republice. 1. vyd. Praha: SOCIOKLUB, 1999. s. 16-67. ISBN 80-902260-7-8. 


\section{SHS Web of Conferences}

[4] Liégeois, Jean-Pierre: Romovia Cigáni Kočovníci. Dějiny a súčasnost'v európskoom kontexte. Bratislava: Rada Evropy, 1995. 271s. ISBN 80-967380-4-3.

[5] Navrátil, Pavel a kol. Romové v české společnosti. 1.vyd. Praha : Portál 2003. 223 s. ISBN 807178-741-8.

[6] Rabušicová, Milada. Kamanová Lenka. Pevná Kateřina. O mezigeneračním učení. Brno: Muni Press, 2011, ISBN 978-80-210-5750-0.

[7] Romipen [online]. 2003 [cit.16.11.2012] Pativ a ladž. Dostupné http://romipen3.euweb.cz/: pativ a ladž.

[8] Říčan, P. S Romy žít budeme - jde o to jak. 1. vyd. Praha: Portál, 1998. 144 s. ISBN 80-7178250-5.

[9] Silverstein, Merril \& Bengtson, Vern. L. Intergenerational solidarity and the structure of adult child-parent relationships in American families. American Journal of Sociology, 1997, 103 (2), 429-460. ISSN: 0002-9602.

[10] Steward, Michal. Čas Cikánů. 1. vyd. Brno:Barrister \& Principál. 2005. 275s. ISBN 80-7364017-1.

[11] Stojka, Peter. Pát'iv. Úcta - zdvořilost. In: Romano džaniben, 3/1996, s. 35-38. ISSN 1210-8545.

[12] Ševčíková, Stanislava. Sebepojetí Romů v romské lidové slovesnosti. Brno, 2011. disertační práce. Masarykova univerzita. Fakulta sociálních studií. Vedoucí práce Pavel NAVRÁTIL.

[13] Šišková, Tatjana. Specifika práce s romskými dětmi (Komunikační specifika romských dětí). In Řetízek. Sborník příspěvků k metodice práce v organizacích pracujících s romskými dětmi a mládeží. 1. vyd. Praha: Občanské sdružení R-Mosty, 2003. 110s.

[14] Skopalová, J. Vzdělávání romských dětí, možnosti vyrovnání př́ležitostí ve vzdělávání. In Dopita, M., Staněk, A. (Eds.) RVP v praxi učitele výchovy k občanství - se zaměrením na potírání rasové a národostní nesnášenlivosti. Olomouc : Univerzita Palackého, 2005, s. 113-120. ISBN 80-244-1250-0.

[15] Williams, Patrick, Gypsy World, Chicago: The University of Chicago Press, 2003, ISBN 0-22689929-2.

[16] Zabriskie, Ramon. B., \& McCormick, Bryan. P. (2001). The Influences of Family Leisure Patterns on Perceptions of Family Functioning. Family Relations, 50(3), 281-289. ISSN 0197-6664. 